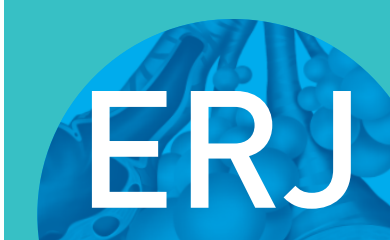

open research

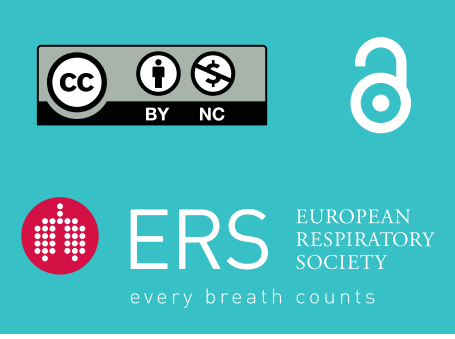

\section{Prevention of aerosol isolation of nontuberculous mycobacterium from the patient's bathroom}

\section{To the Editor:}

Recent clinical studies have revealed that reappearance of the same nontuberculous mycobacterium (NTM) infection is common after successful standard treatment [1, 2]. Using pulsed-field gel electrophoresis analysis, WALLACE et al. [1] found that $\sim 75 \%$ of Mycobacterium avium-intracellulare complex (MAC) isolates identified after successful treatment are the result of reinfection. According to a recent study conducted by $\mathrm{KoH}$ et al. [2] using repetitive sequence-based PCR analysis, all re-identified M. abscessus subsp. abscessus isolates had a unique genotype. Therefore, patients with NTM are exposed to large amounts of microbes in their daily lives, particularly in cases of reinfection.

We performed environmental investigations for pulmonary NTM disease cases using an air sampling method. Interestingly, we identified a case with recurrent pulmonary M. abscessus subsp. massiliense infection who was exposed an identical genotype rather than a different genotype during and after treatment. This report is also the first to show that aero-environmental interventions may be able to prevent reinfection.

All patients were outpatients at Fukujuji Hospital who were diagnosed with pulmonary NTM disease, according to the guidelines of the American Thoracic Society/Infectious Disease Society of America [3]. Chart reviews were used to collect participants' characteristics, including age, sex, infecting mycobacterial species, radiological disease type, and clinical course. Air sampling was performed in the sitting room, the garden (if the patients possessed one) and the bathroom using a SAS SUPER ISO (International PBI S.p.A., Milan, Italy). Air was collected at a rate of $100 \mathrm{~L} \cdot \mathrm{min}^{-1}$ for $10 \mathrm{~min}$ at each site, resulting in a total of $1000 \mathrm{~L}$. In the bathroom, air sampling was performed three times under different conditions: 1) a dry condition, in which the bathroom was not used for over $12 \mathrm{~h}$ prior to sampling; 2) a humid condition, in which hot water was running into the bathtub; and 3) a humid condition created 10-15 min after the bathtub was filled with hot water. The temperature of the water supply was lower than $46^{\circ} \mathrm{C}$. Additional air sampling was performed if a patient possessed a garden and had previously been exposed to soil, regardless of frequency.

A Middlebrook7H11 (Becton Dickinson, Maryland, USA)-based agar plate was prepared according to the method described by THOMson et al. [4], with some modification. Whole-genome sequencing (WGS) was performed to identify the genotype of each isolate [5-10]. All single-nucleotide variant (SNV) sites were extracted by VarScan v2.3.4 [9] using the default parameters, followed by the exclusion of SNV sites in repeat and prophage regions to determine SNV sites in core-genome regions. This study was approved by the Institutional Review Board of the Fukujuji Hospital, Kiyose, Tokyo (No. 17003), and all patients provided written informed consent.

Five patients with pulmonary NTM were investigated. The patients' demographics and clinical courses are detailed in table 1. All patients were female and had nodular-bronchiectatic (NB)-type NTM disease [3]. MAC and M.abscessus complexes were isolated from sputum samples in two and three patients, respectively. All patients had been treated for more than at least 2 months at the time of sampling. Case 5

@ERSpublications

Reinfection of nontuberculous mycobacterium pulmonary disease may be caused by identical and not different genotypes http://ow.ly/62cH30krdpa

Cite this article as: Morimoto K, Aono A, Murase Y, et al. Prevention of aerosol isolation of nontuberculous mycobacterium from the patient's bathroom. ERJ Open Res 2018; 4: 00150-2017 [https://doi.org/10.1183/23120541.00150-2017].

Copyright $\odot$ ERS 2018. This article is open access and distributed under the terms of the Creative Commons Attribution NonCommercial Licence 4.0. 


\begin{tabular}{|c|c|c|c|c|c|c|c|c|c|c|c|c|c|}
\hline \multirow[t]{2}{*}{ Number } & \multirow{2}{*}{$\begin{array}{l}\text { Clinical } \\
\text { species }\end{array}$} & \multirow{2}{*}{$\begin{array}{l}\text { Age } \\
\text { years, } \\
\text { sex }\end{array}$} & \multirow{2}{*}{$\begin{array}{c}\text { Disease } \\
\text { type }\end{array}$} & \multicolumn{4}{|c|}{ Swab samples } & \multicolumn{6}{|c|}{ Air-sampling test } \\
\hline & & & & $\begin{array}{l}\text { Hot water } \\
\text { inlet }\end{array}$ & $\begin{array}{l}\text { Cover of the } \\
\text { hot water } \\
\text { inlet }\end{array}$ & $\begin{array}{l}\text { Shower } \\
\text { head }\end{array}$ & $\begin{array}{l}\text { Kitchen } \\
\text { sink }\end{array}$ & $\begin{array}{l}\text { Bathroom: } \\
\text { dry }^{\#}\end{array}$ & $\begin{array}{l}\text { Bathroom: hot } \\
\text { water running" }\end{array}$ & $\begin{array}{l}\text { Bathroom: } \\
\text { bathtub full of } \\
\text { water }^{+}\end{array}$ & $\begin{array}{l}\text { Sitting } \\
\text { room }\end{array}$ & Potting soil & Garden \\
\hline 1 & M. massiliense & $\begin{array}{l}57, \\
\text { female }\end{array}$ & NB & $\begin{array}{c}\text { AFB } \\
73 \\
\text { colonies }\end{array}$ & $\begin{array}{c}\text { AFB } \\
3+\end{array}$ & $\begin{array}{c}\text { AFB } \\
1 \text { colony }\end{array}$ & $\begin{array}{c}\text { AFB } \\
2+\end{array}$ & $\begin{array}{c}\text { AFB } \\
2 \text { colonies }\end{array}$ & $\begin{array}{c}\text { AFB } \\
3+\end{array}$ & $\mathrm{N} / \mathrm{A}$ & $\mathrm{N} / \mathrm{A}$ & $\begin{array}{l}\text { Contamination } \\
\text { with mould }\end{array}$ & $\begin{array}{l}\text { AFB } \\
25 \\
\text { colonies }\end{array}$ \\
\hline 2 & MAC & $\begin{array}{l}69 \\
\text { female }\end{array}$ & NB & $\begin{array}{c}\text { AFB } \\
33 \\
\text { colonies }\end{array}$ & Negative & Negative & Negative & Negative & $\begin{array}{c}\text { AFB } \\
132 \text { colonies }\end{array}$ & $\begin{array}{c}\text { AFB } \\
86 \text { colonies }\end{array}$ & N/A & $\mathrm{N} / \mathrm{A}$ & $\begin{array}{c}\text { AFB } \\
2 \\
\text { colonies }\end{array}$ \\
\hline 3 & MAC & $\begin{array}{l}69, \\
\text { female }\end{array}$ & NB & Negative & Negative & Negative & Negative & Negative & Negative & Negative & Negative & $\mathrm{N} / \mathrm{A}$ & N/A \\
\hline 4 & M. abscessus & $\begin{array}{l}\text { 66, } \\
\text { female }\end{array}$ & NB & $\begin{array}{c}\text { AFB } \\
33 \\
\text { colonies }\end{array}$ & Negative & Negative & $\begin{array}{c}\text { AFB } \\
2+\end{array}$ & $\begin{array}{c}\text { AFB } \\
1 \text { colony }\end{array}$ & $\begin{array}{c}\text { AFB } \\
2+\end{array}$ & $\begin{array}{c}\text { AFB } \\
16 \text { colonies }\end{array}$ & $\mathrm{N} / \mathrm{A}$ & N/A & $\begin{array}{c}\text { AFB } \\
2 \\
\text { colonies }\end{array}$ \\
\hline 5 & M. massiliense & $\begin{array}{c}71, \\
\text { female }\end{array}$ & NB & Negative & N/A & Negative & $\begin{array}{c}\text { AFB } \\
3+\end{array}$ & $\begin{array}{c}\text { AFB } \\
1 \text { colony }\end{array}$ & $\begin{array}{l}\text { M. massiliense } \\
65 \text { colonies }\end{array}$ & Negative & Negative & $\begin{array}{c}\text { AFB } \\
9 \text { colonies }\end{array}$ & $\begin{array}{l}\text { AFB } \\
1 \text { colony }\end{array}$ \\
\hline $\begin{array}{l}5 \text { (Second } \\
\quad \text { investigation) }\end{array}$ & & & & Negative & Negative & $\begin{array}{c}\text { AFB } \\
2 \\
\text { colonies }\end{array}$ & $\mathrm{N} / \mathrm{A}$ & Negative & $\begin{array}{l}\text { M. massiliense } \\
19 \text { colonies }\end{array}$ & Negative & N/A & Negative & N/A \\
\hline
\end{tabular}


was under a second course treatment that had lasted for 5 months. The first treatment ended 10 months ago and recurrence was diagnosed 7 months ago. Negative conversions of culture were obtained in patients 1,3 and 5, whereas the other two patients showed consecutive culture-positive results for more than 24 months.

Regarding the results of air sampling in the bathroom, several NTM colonies were isolated from the sampled air, even $12 \mathrm{~h}$ after the last use (i.e. under relatively dry conditions) (table 1). However, the number of NTM colonies in the air increased markedly when hot water was running (generating water vapour), with the exception of the sample from the bathroom of patient 3. Furthermore, the number of colonies decreased under less humid conditions in the bathrooms of all four patients after the bathtub was filled with hot water. In patient 5, whose was infected with M. massiliense, the same species was detected in the air while hot water was running (65 colonies), whereas no NTM was detected in the air after supplying hot water or from the swab samples. WGS analysis using two and three isolates from the patient's specimens and the environment, respectively, identified only three SNVs among the five, which were thought to be identical [11].

The first examination of patient 5 was conducted during treatment of her second M. massiliense disease, which was successfully completed 1 -year after culture reversion ( 8 months after the examination). The patient stopped using the bathtub after the first investigation. The next environmental investigation was conducted 1 year after the first investigation; M. massiliense with an identical genotype was again isolated after running hot water into the bathtub (table 1). After the patient stopped bathtub use, no recurrence of M. massiliense infection was observed, even with persistent bronchiectatic changes. The sputum samples were negative 12 times and no radiological progression was observed.

In case 5, the two separate collections of swab samples from the hot water inlet did not yield M. massiliense, but the pathogen was isolated from the air with running hot water. We therefore concluded that NTM might exist deep inside of the piping system and that simple cleaning of the inlet may be insufficient to remove the pathogen. Interestingly, even with the same system, M. massiliense was not detected (only seven colonies of other NTM were identified) from the air when the shower was running. Thus, the patient stopped using the bathtub after the first examination, but still uses the shower. Based on this result, the infection control measure, i.e. no use of the bathtub and suppression of the aerosol in this case, may be able to prevent reinfection with NTM.

As a certain NTM in the environment can exist as various genotypes, reinfection is generally thought to be caused by different genotype $[1,2,12]$. Discrimination of genotypes in first and second NTM infections has been performed using several genetic methods. Recently, WGS analysis has shown the highest discrimination power. Studies performing WGS analyses of M. tuberculosis isolates showed that most relapses are caused by reactivation of the same pathogen/genotype and reinfection with a different genotype is rare. This finding may be due to the rare chance of exposure to M. tuberculosis even in a setting with high TB prevalence, and the acquired immunity against TB would lower the possibility of reinfection with another genotype [11]. In addition, NTM patients have a high risk of reinfection because of the ubiquitous presence of NTM. Based on the air sampling and WGS results from the present study, NTM patients may be frequently exposed to aerosolised pathogens and infected repeatedly by the identical genotype from their environment, particularly in a small space like the bathroom. Therefore, identification of the infection route and identical genotype by WGS will be of great importance to demonstrate the occurrence of relapse. We believe that further analyses to clarify this infection control measure, including comprehensive environmental analysis of NTM genotype, is warranted.

In conclusion, this study identified, for the first time, the same genotype of M. massiliense from a patient and the aero-environment. Our findings also indicate that appropriate infection control measures should be based on environmental investigation. The preventive measure taken in this study indirectly demonstrates that recurrent NTM infections can be caused by reinfection and not by relapse. Overall, the proportion of recurrent cases due to reinfection may be higher than expected.

Kozo Morimoto ${ }^{1,2,3,5}$, Akio Aono ${ }^{3,5}$, Yoshiro Murase ${ }^{3}$, Tsuyoshi Sekizuka ${ }^{4}$, Atsuyuki Kurashima ${ }^{2}$, Akiko Takaki $^{3}$, Yuka Sasaki ${ }^{2}$, Yuriko Igarashi ${ }^{3}$, Kinuyo Chikamatsu ${ }^{3}$, Hajime Goto ${ }^{2}$, Hiroyuki Yamada $^{3}$, Makoto Kuroda $^{4}$ and Satoshi Mitarai ${ }^{3}$

${ }^{1}$ Division of Clinical Research, Fukujuji Hospital, Japan Anti-Tuberculosis Association, Tokyo, Japan. ${ }^{2}$ Respiratory Disease Center, Fukujuji Hospital, Japan Anti-Tuberculosis Association, Tokyo, Japan. ${ }^{3}$ Dept of Mycobacterium Reference and Research, The Research Institute of Tuberculosis, Japan AntiTuberculosis Association, Tokyo, Japan. ${ }^{4}$ Pathogen Genomics Center, National Institute of Infectious Diseases, Tokyo, Japan. ${ }^{5}$ Both authors contributed equally. 
Correspondence: Kozo Morimoto, Division of Clinical Research, Fukujuji Hospital, Japan AntiTuberculosis Association, 3-1-24, Matsuyama, Kiyose, Tokyo, 204-8522 Japan. E-mail: morimotok@ fukujuji.org

Received: Nov 212017 | Accepted after revision: May 292018

Acknowledgements: The authors express their sincere appreciation to Masaru Nakagawa (Nakagawa Internal Medicine Pediatrics Clinic, Fujimi city, Japan) for his valuable advice.

Conflict of interest: None declared.

This work was supported by the Research Program on Emerging and Re-emerging Infectious Diseases from the Japan Agency for Medical Research and Development, AMED under grant number JP18fk0108043. Funding information for this article has been deposited with the Crossref Funder Registry.

\section{References}

1 Wallace RJ Jr, Brown-Elliott BA, McNulty S, et al. Macrolide/azalide therapy for nodular/bronchiectatic Mycobacterium avium complex lung disease. Chest 2014; 146: 276-282.

2 Koh WJ, Jeong BH, Kim SY, et al. Mycobacterial characteristics and treatment outcomes in Mycobacterium abscessus lung disease. Clin Infect Dis 2017; 64: 309-316.

3 Griffith DE, Aksamit T, Brown-Elliott BA, et al. An official ATS/IDSA statement: diagnosis, treatment, and prevention of nontuberculous mycobacterial diseases. Am J Respir Crit Care Med 2007; 175: 367-416.

4 Thomson R, Tolson C, Carter R, et al. Isolation of nontuberculous mycobacteria (NTM) from household water and shower aerosols in patients with pulmonary disease caused by NTM. J Clin Microbiol 2013; 51: 3006-3011.

5 Sekizuka T, Kai M, Nakanaga $\mathrm{K}$, et al. Complete genome sequence and comparative genomic analysis of Mycobacterium massiliense JCM 15300 in the Mycobacterium abscessus group reveal a conserved genomic island MmGI-1 related to putative lipid metabolism. PLoS One 2014; 9: e114848.

6 Jiang H, Lei R, Ding SW, et al. Skewer: a fast and accurate adapter trimmer for next-generation sequencing paired-end reads. BMC Bioinformatics 2014; 15: 182.

7 Li H, Durbin R. Fast and accurate long-read alignment with Burrows-Wheeler transform. Bioinformatics 2010; 26 589-595.

8 Zhou Y, Liang Y, Lynch KH, et al. PHAST: a fast phage search tool. Nucleic Acids Res 2011; 39: W347-W352.

9 Koboldt DC, Chen K, Wylie T, et al. VarScan: variant detection in massively parallel sequencing of individual and pooled samples. Bioinformatics 2009; 25: 2283-2285.

10 Sekizuka T, Yamashita A, Murase Y, et al. TGS-TB: total genotyping solution for Mycobacterium tuberculosis using short-read whole-genome sequencing. PLoS One 2015; 10: e0142951.

11 Witney AA, Bateson AL, Jindani A, et al. Use of whole-genome sequencing to distinguish relapse from reinfection in a completed tuberculosis clinical trial. BMC Med 2017; 15: 71.

12 Nishiuchi Y, Maekura R, Kitada S, et al. The recovery of Mycobacterium avium-intracellulare complex (MAC) from the residential bathrooms of patients with pulmonary MAC. Clin Infect Dis 2007; 45: 347-351. 